\title{
Beyond the ritual of exchange: The culture of alienation shared between soldiers along the Rappahannock during the winter of 1862--63
}

Lauren Kristin Thompson

West Virginia University

Follow this and additional works at: https://researchrepository.wvu.edu/etd

\section{Recommended Citation}

Thompson, Lauren Kristin, "Beyond the ritual of exchange: The culture of alienation shared between soldiers along the Rappahannock during the winter of 1862--63" (2010). Graduate Theses, Dissertations, and Problem Reports. 772.

https://researchrepository.wvu.edu/etd/772

This Thesis is protected by copyright and/or related rights. It has been brought to you by the The Research Repository @ WVU with permission from the rights-holder(s). You are free to use this Thesis in any way that is permitted by the copyright and related rights legislation that applies to your use. For other uses you must obtain permission from the rights-holder(s) directly, unless additional rights are indicated by a Creative Commons license in the record and/ or on the work itself. This Thesis has been accepted for inclusion in WVU Graduate Theses, Dissertations, and Problem Reports collection by an authorized administrator of The Research Repository @ WVU. For more information, please contact researchrepository@mail.wvu.edu. 
Beyond the Ritual of Exchange:

The Culture of Alienation Shared Between Soldiers

Along The Rappahannock during the Winter of 1862-63

\title{
Lauren Kristin Thompson
}

Thesis submitted to the College of Arts and Sciences

At West Virginia University

In partial fulfillment of the requirements

For the degree of

\author{
Master of Arts \\ In \\ History
}

\author{
Peter S. Carmichael, Ph. D, Chair \\ Brian P. Luskey, Ph. D \\ John Ernest, Ph. D
}

Department of History

Morgantown, West Virginia

2010

Keywords: Fraternization; Civil War; soldiers;

Battle of Fredericksburg; Rappahannock River;

Confederate; Union; culture of alienation.

Copyright 2010 Lauren K. Thompson 


\title{
Abstract \\ Beyond the Ritual of Exchange: The Culture of Alienation Shared Between Soldiers Along The Rappahannock during the Winter of 1862-63
}

\author{
Lauren K. Thompson
}

Between December 1862 and April 1863, the Confederate Army of Northern Virginia and Union Army of the Potomac remained stalemated across from one another on the Rappahannock River. Following the victory at the Battle of Fredericksburg, the Confederate Army held the city while the Union forces remained across the river in Falmouth, Virginia. Soldiers on both sides had several reasons for discontent at this point in the war. The larger causes that drove these men to enlist and fight faded as larger political issues, incompetent commanders, and the difficulties of camp life intensified. Union and Confederate soldiers felt infringement on their independence and looked for other ways to regain their manhood. While soldiers on both sides took their turn on picket duty, they were only a stone's throw away from their enemy. The permeability of the river and a truce against firing allowed for quite possibly the largest instance of fraternization throughout the Civil War.

. While soldiers sat on picket duty across from their enemy, they sang songs, shared jokes, and shouted to one another. As this behavior became accepted, soldiers sent sailboats across with coffee in exchange for tobacco and vice versa. Newspapers were also a hot commodity for exchange. Despite ordinances by both General Lee and General Hooker, soldiers continued to trade items and even began to cross the river. Why would soldiers risk their lives for an enemy that weeks earlier they fought against at the Battle of Fredericksburg? The answer to this question lies in the analysis of the deeper meaning of fraternization, which is at the center of this study. Fraternization was not just an exchange of coffee and tobacco, but served as a larger purpose and had a very complex meaning. When soldiers met one another across enemy lines, they shared stories of home and combat, and talked of peace. These interactions were possible through a common soldier culture of alienation. Confederates were able to relate to disheartened Union soldiers through a common bond of sacrifice and honor. As seasoned veteran soldiers, Federals and Confederates felt that they had more in common with one another than the generals who led them and the politicians at home. This culture of alienation created a bond that was strong enough for these men to travel behind enemy lines, exchange commodities, and share emotions. Fraternization was a subtle form of dissent and did not deter men from staying and they continued to fight at Chancellorsville. The same unity and empathy that brought these men together on the Rappahannock, kept them in their ranks. Therefore, the unique culture developed through fraternization serves as a tool in the development of the synthesis of the Civil War soldier experience. 


\section{Table of Contents}

Introduction................................................1

Chapter I: The Evolution of Fraternization...................10

Chapter II: Analyzing Beyond the Ritual of Exchange.......24

Chapter III: Fraternization and Reconciliation...............41

Conclusion......................................................47

Citations......................................................52 


\section{Introduction}

During the winter of 1862-1863, the Confederate Army of Northern Virginia and the Union Army of the Potomac came to the small town of Fredericksburg, Virginia. For five months, roughly 200,000 Union and Confederate soldiers straddled the Rappahannock River. Although the Battle of Fredericksburg only lasted three days, the armies remained encamped across from one another throughout the cold winter months. Prior to the battle, the monotony of army life and strict rule by the officers threatened the independence and the manhood of the men on both sides. Despite these threats, the larger causes of country, courage, and honor overshadowed discontent in the ranks with the majority of the soldiers. However, after the bloodshed at Fredericksburg, consequences for both armies led to dissent and desertion. For those who stayed the course, the larger causes seemed to dwindle. Therefore, for those who felt that the rigors of army life threatened their independence, they needed to redefine their meaning of manhood. In order to regain their manhood, men would dissent in subtle ways. This disillusionment experienced by soldiers on both sides created a culture of alienation. This experience is a culture because it is defined by the actions and emotions of these men who tried to make sense of the war. In order for this culture to be recognized between enemies, the time and place had to be right. Due to the closeness of the picket line and the permeability of the Rappahannock, the situation welcomed fraternization. Although fraternization occurred during other campaigns throughout the war this study shows that during the winter of 1862-63, soldiers related to each other in significant ways. These encounters created a culture of alienation at this point in the war. 
In both military and academic history, scholars have devoted countless hours of research and analysis to Civil War soldiers. Historians continue to write entire books on one battle that are broken down into one day or one portion of that battle. Military scholars recount minute-by-minute movements of how each unit went across the field to meet the enemy across that deadly space. This type of analysis brings up two important aspects of the Civil War: time and space. Scholars often neglect the significant moments between battles. As historians focus on soldier experience, the trend is to jump from battle, ignoring the important aspects camp life had on soldiers and their identity. Though recent historiography highlights the overall experience of camp life, it is difficult to find literature on the time between large battles. Specifically between the Army of the Potomac and the Army of Northern Virginia, the soldier experience during the winter of 1862-1863 is largely absorbed into political history of the Emancipation Proclamation and the new Command of Union General Joseph Hooker. Between the battles of Fredericksburg and Chancellorsville spanned a six-month period where the soldiers remained encamped. What links time to space is the encampment of the armies separated by only a few hundred yards of the Rappahannock River. In the field of Civil War Military History, the scholarship focuses on the space that separated the enemies on the day of the battle, but what about the space that separated them for six months? This fivemonth period and the space of the Rappahannock River, served as a venue where soldiers realized they shared a culture of alienation. Arguably, this culture linked supposed enemies to one another in more ways then they thought possible.

The first intention of this paper is to retrace the actions and experience of the soldiers during the winter of 1862-1863 on the Rappahannock River. Since I argue that 
this culture of alienation is revealed through the act of fraternization, Chapter 1 retraces the evolution of fraternization through the actions and language of the soldiers. Due to an abundance of letters and diaries from the soldiers, historians have written about the armies during the Battle of Fredericksburg. The definitive studies of the battle are Frank O’Reilly’s, Fredericksburg: Winter War on the Rappahannock and George Rable's, Fredericksburg! Fredericksburg!. These studies highlight the context of the battle and the condition of the armies after the humiliating Union defeat. O’Reilly and Rable use a broad spectrum of sources, both from commanders and soldiers, to construct a narrative of the battle. A small portion of the narrative of the battle was the winter encampment along the Rappahannock River. With ample time to write in diaries and write letters home, soldiers regularly wrote about the interaction with the enemy.

Just as soldiers met their enemies face to face on the battlefields, they met face to face across the river during the winter. Commanders looked negatively on fraternization with the enemy despite their own instances of fraternization with old friends whom they met at West Point Military Academy prior to the war. Since enemies separated each other by only a few hundred yards of water, the geography contributed to the soldiers' ability to fraternize. A common truce to cease-fire while on picket duty only lessened the sense of fear associated with partaking in this illegal activity. Almost immediately after the Battle of Fredericksburg, soldiers began to converse across the river with their enemy. Conversation began with the shouting of jokes and continued with the trading of southern tobacco for northern coffee. Before long, men began to travel across the river in boats and host one another across enemy lines for a night. The emotions associated with fraternization evolved just as did the actions. Soldiers both North and South wrote in 
diaries and in letters home about their experiences meeting the enemy. These letters illustrated transforming perceptions of the enemy as the fraternization led to the soldiers humanizing their opponents and viewing them as men and friends. The interactions that took place over five months during the war created a unique soldier culture. The second goal of this paper is to examine beyond how these men fraternized, and move below the surface to discover exactly what that culture represented and why it developed.

Since the study of the common soldier began with Bell Irvin Wiley's Life of Johnny Reb and Life of Billy Yank, historians have since analyzed incidents of soldier fraternization. ${ }^{1}$ For example, Wiley states, "One who reads extensively the literature of the war period, and especially the letters and diaries of soldiers, finds numerous indications of friendly sentiment among opposing participants." " He goes on to write, "If the grim fact of the contestants actually meeting right now and then in desperate battle could be overlooked, it might be inferred that good feeling outweighed hostility.”3 Willey argues that shared qualities of character such as honor, devotion, and manliness attributed to friendliness among foes. ${ }^{4}$ Traditionally, the trade of coffee and tobacco on the Rappahannock River characterizes fraternization. Some historians have investigated the reasons behind fraternization. For example, James Robertson argues, "the majority of men on both sides never felt any strong animosity toward those across the way." ${ }^{5}$ George Rable analyzes fraternization in his analysis of soldier experience at Fredericksburg by arguing that fraternization illuminates the confidence of the Confederate soldiers. ${ }^{6}$ My argument supports that not only was fraternization friendly and benevolent, but also went beyond the notion of boredom. Letters and diaries reveal that soldiers were bored with the monotony of camp life and did yearn for tobacco and coffee while camped along the 
river. However, I argue that the boredom and trading of goods was the initial draw towards fraternization. Nevertheless, as these men conversed and learned more about each other, a unique culture of alienation developed. Through this culture, a new perspective into the common soldier is visible.

The culture of alienation developed because of their common traits of nineteenthcentury manhood and masculinity. Fraternization provided a window into who these men were before the war and how the values they brought with them shaped how they viewed their enemy. As agents of political propaganda during the sectional crisis, these men only heard about their enemy in newspapers and community discussions but never met. Only after meeting their enemy, soldiers realized they have more in common than they thought. Private Morton Hayward of the $7^{\text {th }}$ Massachusetts Infantry recorded such an experience. Hayward described his interaction with pickets from the $7^{\text {th }}$ Georgia Infantry by writing, “The Rebel Pickets were close by on the opposite side of the river and we could and did talk and trade with them. The Reb’s had two boats in which they would cross over with their tobacco and Richmond papers to exchange for our coffee and papers. They said they were sick of the war and wished that they might go home to their families.” ${ }^{7}$ Both Union and Confederate soldiers wrote letters and diary entries showing similar sentiments. Soldiers talked, traded, and shared common dialogue about the end of the war and the desire to go home. Whether the enemy soldiers mingled for trade, picked blackberries, buried the dead, met with friends of prewar days, and exchanged newspapers, they came together for periods of pleasant association. ${ }^{8}$ What drove these men to share such emotions and risk their lives to do so, but ultimately pick up their rifles and fight again at Chancellorsville? This study strives to show how a common culture of 
alienation welcomed these exchanges and how the culture developed further among soldiers during fraternization as the armies prepared for the next campaign.

Chapter 2 will look deeper into the analysis of fraternization as a culture of alienation for the men who participated. It is necessary to understand nineteenth-century culture in order to understand the culture of the alienation. The men risked their lives on the battlefield to kill the enemy, but then risked their lives to eat breakfast with that same enemy. Analysis of the culture of alienation and notions of a "Rich Man's War Poor Man's Fight” are necessary to understand this question. These intimate interactions require the investigation of the common soldier as a product of political propaganda as self-made men and an analysis of the larger causes for why these men fought. After fraternization on the Rappahannock, was the motivation that drove these men to fight in 1861 the same motivation that kept these men fighting that summer? Alternatively, did these soldiers realize that slavery and states rights related more to politicians and less to them? There is no conclusive evidence to show that soldiers disserted after fraternization. However, many soldiers learned that what drove their enemy to pick up the rifle was the same reason why they chose to as well. The conclusions soldiers drew from the culture of alienation on the Rappahannock served as questions for analysis that this study investigates.

The third area of analysis is the use of fraternization in postwar publications to help reconcile. Scholars often argue that fraternization is an embellishment of postwar individuals who attempted to show that since enemies could get along during the war, they could have no problem getting along after. These occurrences when Union and Confederate soldiers met and conversed not only revealed a common culture of 
alienation, but also demonstrated the nature of a war between fellow citizens. Men easily spoke with one another because they spoke the same language and had several commonalities such as culture, fighting motivations, family, and a sense of brotherhood. The fraternization during the Civil War, especially on the Rappahannock, is particularly unique in warfare. Since fraternization highlights friendship between enemies during the war, it was a topic of interest afterward for reconciliationists. There were postwar sources that describe these instances of fraternization through the memory of soldiers on the Rappahannock. Therefore, this debate raises another question: was fraternization truly significant during the Civil War or was it simply a tool of the reconciliationists? Are the commonalities between enemies shared during fraternization what really happened or what postwar accounts want us to think happened? Chapter 3 reveals the postwar use of fraternization as a reconciliationist tool for Civil War memory without undermining the significance of fraternization during the war.

The most effective way to analyze the culture of alienation is through letters and diaries. ${ }^{9}$ By using the words the soldiers left behind, a better understanding of the politics and culture surrounding the winter of 1862-63 is identifiable. These first-hand accounts came from both Union and Confederate soldiers who wrote letters home or in their personal diaries during that winter stationed along the Rappahannock River. Chapter 3 will analyze post-war recollections of fraternization, but for the analysis of the culture of alienation, wartime sources are used in order to get the closest measure of personal accounts of fraternization. The letters and diaries came from mostly private soldiers. However, there are several accounts of higher-ranking officers, including generals, in the attempt to get a larger perspective on the act of fraternization. All of these 
accounts are from men who fit two particular criteria: first, they volunteered for the war and second, they were involved in the Battle of Fredericksburg. Since this study analyzes army life's impact on these soldiers and their motivation to enlist, it is imperative that soldiers be volunteers and that they experienced the bloodshed of Fredericksburg. This includes men who did not fraternize, because they witnessed it, wrote what they saw, and offered differing opinions on the dissent associated with fraternization. The majority of these letters and diaries are from the Fredericksburg and Spotsylvania National Military Park archives where both Union and Confederate soldiers’ letters and diaries are accessible.

The study of soldiers on the Rappahannock River does not serve to redefine why men fought, but simply adds another layer to the intricate study of soldier motivation. Soldiers were under strict orders against fraternization but chose to anyway. An intricate analysis of the soldier discourse provides a new perspective towards the men who fought. The Rappahannock is not the only site of fraternization throughout the war; several occurrences take place on other rivers, however, the fraternization that occurred during the winter of 1862-1863 is arguably the most prominent and memorable account throughout the war. Historical sites dedicated exhibits in museums with depictions of fraternization, military historians quote soldiers trading during their battlefield tours, Hollywood has depicted scenes of fraternization in movies on the Civil War, and academic historians noted it in their books on the common soldier. Dismissing fraternization as simply boredom may ignore important aspects of the men who fought and how interaction with the enemy was such a significant experience. Perhaps a farmer from Georgia had the same motivation to fight as did a factory worker from 
Massachusetts. According to historian James I. Robertson Jr., “America has never known a war where fraternization ran so rampant." ${ }^{10}$ Why was fraternization so common? If there were laws against it, why would common soldiers still take the risk to converse with the enemy? This study looks at how and why soldiers chose to fraternize in the wake of such bloodshed. Most importantly, if fraternization was so popular, what characteristics did these soldiers embody that allowed for this behavior to occur at such a widespread rate? The interactions on the Rappahannock River between Union and Confederate soldiers provide insight into the common soldier through their common culture of alienation. 


\section{Chapter I: The Evolution of Fraternization}

The subordination associated with army life threatened the individualism and independence of both Union and Confederate soldiers. However, larger causes such as patriotism and country kept the majority of them motivated to stay the course of the war. After the Battle of Fredericksburg, many soldiers lost hope in the cause that drove them to fight and thus they had to reclaim their manhood. One of the main ways men regained their manhood was through dissent of orders against fraternization. Fraternization took place and evolved into a culture on its own. The culture that drove these men to fraternize cultivated when men realized their enemies yearned for the same outlet because of similar feelings of discontent. Therefore, during the winter of 1862-1863 a unique culture of alienation developed among the common soldiers.

There are several levels to the study of soldier fraternization but in order to understand the deeper meaning, first one must understand the nature and evolution of the interactions along the Rappahannock. During the winter of 1862-1863, the Battle of Fredericksburg brought the armies to the Rappahannock River and the outcome of the battle kept the armies in place over the winter months. The interesting aspect of fraternization is that it occurs before, during, and after the Battle of Fredericksburg. Fraternization started as a few jokes then evolved into a trade network and eventually into an exchange of thoughts, feelings, and emotions between enemies. This sphere of exchange highlighted the culture of alienation. This chapter strives to reveal the evolution of individual acts of fraternization. 
When the armies arrived to the banks of the Rappahannock in late November 1862, the geography and battle lines set the stage for fraternization. The Confederates occupied the banks in the town of Fredericksburg and the Union troops occupied the banks opposite of the city in a town called Falmouth, Virginia. Before the Battle of Fredericksburg in mid-December 1862, Generals ordered Union and Confederate soldiers to picket duty where some fraternization occurred. For most of these men this was the first chance they were able to see their enemy so easily. A private in the $1^{\text {st }}$ Minnesota wrote, “General Gibbon's Division, to which the $1^{\text {st }}$ Minnesota belonged, was in camp just below Chatham, commonly called the Lacy House, which was so often headquarters of the Union Generals. The camp was near the river and within direct range of the three hundred CSA cannon along Marye's Heights only a mile away. Just along the narrow and fordable river were camps of Confederate Infantry and the opposing pickets were almost within a stone's throw of one another. Loud conversations were easily heard and though talking was strictly forbidden by each side, there was a great deal of good natured badinage indulged between these deadly enemies." ${ }^{11}$ Even before the battle, due to the proximity of the armies, men chose to disobey orders and shared conversation before the bloodshed began. Confederate General Thomas R.R. Cobb noted, "Nothing separates us from the Yankees here but the Rappahannock River. In some places, it is not a hundred yards wide. Their picket line on one bank while ours occupy the other. During the day, the men walk about in plain sight of each other. I noticed the rascals eyeing me through a spyglass and I rode down the lines today. By tacit agreement there is no firing along the picket line." ${ }^{22}$ Therefore, the location of the armies before the battle allowed for conversations between enemies. Although, fraternization was not as significant as it 
would be after the battle. The bloodshed at Fredericksburg would change the nature of these interactions into something larger.

Fraternization between enemies even happened during the Battle of Fredericksburg. During the Fredericksburg Campaign along the Rappahannock, posted both North and South of the city in order to guard fords at the bend in the river and at Port Royal, stood the cavalry soldiers. On December $20^{\text {th }}, 1862$ Richard Watkins of the $3^{\text {rd }}$ VA Cavalry wrote, “Our regiment was on picket duty on the extreme left of the line and was not engaged in the fight... while the fight was going on, our pickets were in a most quiet manner conversing with the enemy pickets across the Rappahannock...Henry Ewing \{and some of our men \} actually gone over and taken breakfast with a portion of the $6^{\text {th }}$ New York Cavalry.” 13 This example demonstrates that Union and Confederate soldiers conversed together along the Rappahannock while their comrades slaughtered one another on the battlefield. This was a significant, but also rare occasion when friendly enemy contact happened during a battle.

The majority of fraternization occurred after the Battle of Fredericksburg. Before analyzing the deeper meaning of these interactions, one must investigate the outcome of the battle and its effects on the soldiers.

The Battle of Fredericksburg is the most humiliating defeat for the Union Army of the Potomac. The Army of the Potomac’s leader, General Ambrose E. Burnside was under intense pressure from the Lincoln Administration to bring victory to the country before the onset of winter. After the bloody Battle of Antietam, Lincoln lost support for the Republican Party in November 1862 elections. Therefore, in order to rally support for the war on the home front, the Army needed a victory. Secondly, President Lincoln 
issued the Preliminary Emancipation Proclamation in September 1862. On January 1, 1863, the official Emancipation Proclamation was set to go into effect. Previously President Lincoln argued that the war was not about slavery and he hoped to save the union without touching the issue of slavery. ${ }^{14}$ After two years of bloody conflict and several Union Army defeats on the battlefield, Lincoln changed his policy towards the issue of slavery. Thus, Lincoln wanted to piggyback the Emancipation on a decisive Union Victory. However, despite plans to attack the city of Fredericksburg and move south towards the Confederate capital of Richmond, bureaucratic delay and miscommunication in the Union high command kept victory out of reach for the Army of the Potomac. ${ }^{15}$

For the common soldier, the Battle of Fredericksburg was a disheartening experience for even the seasoned veteran. On December 13' 1862, the Union Army sent seven divisions of men, divided into sixteen brigades, wave by wave uphill over open ground in attempt to break the Confederate position behind a stonewall. ${ }^{16}$ George Rable describes, "Because of the terrain at Fredericksburg, soldiers had observed wholesale dying firsthand. Normally men saw little beyond their own regiment or even their own company, but the wider vistas of this battlefield had intensified the horror." ${ }^{17}$ After nightfall on the $13^{\text {th }}$, Union soldiers were pinned on the field for two days until Burnside ordered a retreat into the town and fled back across the Rappahannock. The total casualties were 12,653 Union and 5,309 Confederate. ${ }^{18}$ These losses that made their way back to families across the nation over the next few weeks, made 1862 one of the gloomiest Christmases in American history. 
The defeat at Fredericksburg illuminated problems in the command structure of the Army of the Potomac. The commanders seemed to be more concerned in competing with one another, rather than with the moral state of their men. George Rable states, “Complaints about self-promoters who would sacrifice lives to advance or destroy careers made for bitter camp conversations." ${ }^{19}$ Pvt. William Hamilton of the $2^{\text {nd }}$ Pennsylvania Infantry confessed, "Something must be done to either relieve us or our commanders”. ${ }^{20}$ Former commander of the Army of the Potomac, General George B. McClellan was reluctant to attack and harshly criticized by the Lincoln Administration, while General Ambrose E. Burnside commenced a quick attack that led to criticism of the slaughter. Lt. Theodore Dodge of the $119^{\text {th }}$ New York Infantry argued, "I have no faith in our leaders, I am glad to see that the government has begun to dismiss officers who fail in their duty."21 The large number of the Union soldiers could not promise victory. The soldiers as well as the civilians were unhappy with the leadership in the Army of the Potomac.

For the soldiers who had experienced death and despair, after the Battle of Fredericksburg the disappointment in General Burnside’s leadership continued. The final straw for General Burnside was the fateful “Mud March”. When Burnside led his men on a march on January 20, 1863, it was ruined with intense rain the caused the whole army to become stuck in mud. ${ }^{22}$ Spirits within the ranks sunk even lower and caused thousands of men to desert. Private Wyman White described the experience as, "Hundreds of men, being entirely discouraged, broke to the rear and started toward the north and home. Not because they were not patriotic but because they were discouraged beyond endurance”23. General Burnside was relieved of command on January 25, 1863 
and replaced by General Joseph Hooker. ${ }^{24}$ However, for those who chose to stay the course, it was not without difficulties.

The discouragement the Union Army faced at this point directly threatened the manhood and independence of the soldiers. The Army of the Potomac settled into their winter encampment directly across the river from the battlefield where they lost so many of their comrades. Thousands of men complained about army life, their officers, and the politicians. One soldier wrote to his wife on Christmas Eve, "The army appeared disheartened, in fact completely discouraged. I can hardly find any three men that have confidence in one man. I don't know how it appears to you up away out of reach of this terrible rebellion, but here at this time I must confess everything wears a dark, gloomy aspect”25. Walt Whitman witnessed this despair while spending time at a field hospital in Falmouth, Virginia. Whitman noted, "Death is nothing here. As you step out in the morning from your tent to wash your face, you see before you on a stretcher a shapeless, extended object and over it is thrown a dark grey blanket. It is the corpse of some wounded or sick soldier of the regiment who died in the hospital tent during the night; perhaps there is a row of three or four of these corpses lying covered over. No one makes an ado". ${ }^{26}$

For the Army of Northern Virginia, one would have expected it to be a joyous and hopeful time for the common soldier. Southerners did rejoice over the victory, although their morale was lower than one would expect. Southern newspapers reported mixed emotions after the Battle of Fredericksburg. ${ }^{27}$ First, many soldiers felt Lee's reluctance to counterattack was costly. Lee lost nothing less than his opportunity to end the war and he personally felt the Confederates had accomplished nothing. ${ }^{28}$ One soldier reported, "We 
had not gained a foot of ground and I knew that the enemy could replace the men he had lost." 29 Unlike the Union soldiers, the Confederates had faith in their officers and held a strong sense of confidence. Nevertheless, as the Confederate soldiers sat in the town of Fredericksburg during the winter of 1863, they watched the Union Army fill up the gaps in their ranks they previously punctured during the battle. Joseph Hooker’s Army grew to a larger size than it had been before the battle at Fredericksburg. In addition, almost all of the men confessed to being homesick. The cost of victory loomed fresh in their minds and men shuddered when they thought of the sacrifices required of the living. Many soldiers felt unfulfilled because they won victory, but the war continued and they gave the ultimate sacrifice for what gain? Historian George Rable states, "Worries about the army’s (and the country’s) spiritual state in part grew out of a loneliness that ate away at morale even in a victorious army." 30 The Confederate Army knew that the worst was yet to come and victory would not be without more bloodshed. Therefore, despite the victory at Fredericksburg, the Confederate soldiers had grievances of their own and they went into the year of 1863 far from content.

While both the Union and Confederate armies had their own reasons for discontent and low morale at the close of 1862, the boredom and monotony of camp life did not make things easier for these men. Besides constant drills, soldiers participated in snowball fights, baseball games, and wrote letters home. Even the strongest soldiers felt the monotony and boredom of camp. Homesickness and illness were common at this time, but more disheartening was camp life on both sides of the Rappahannock, that reverted to routine and things were very dull. To keep men from boredom, Officers ordered men to conduct drills, inspections, manual labor, and picket duty, which only 
angered men who had to do useless tasks. One New Jersey solider stationed by Aquia Creek described this work to his brother as, "If you has seen the hardships that I have since I left Washington then you never would come down here for to be nigered.” 31 The boredom of camp and the routine labor led men to become even more disgruntled with their position in the army and turned to an outlet to reclaim their manhood: fraternization.

When soldiers searched for an outlet to dissent, picket duty was the ideal opportunity. Both Union and Confederate regiments took a twenty-four hour shift about every nine days stationed on the banks of the Rappahannock along a one and one half mile range of shoreline, with about thirty men at each quarter-mile interval ${ }^{32}$. Picket duty, although extremely demanding, gave the soldiers a chance to escape drills. On the banks of the Rappahannock River, pickets were in shouting range of one another. While stationed only a few hundred yards from one another, with an agreement to cease-fire and at a distance from their officers, soldiers were able to fraternize. Curiosity about the enemy broke up the monotony of picket duty and men began to converse. Just as fraternization occurred before and during the Battle of Fredericksburg, it continued most frequently after the battle. Fraternization evolved from simple acts of curiosity that were marked by shouts and jokes, to the meeting of enemies on either side of the river. The evolution of these interactions reveals the ritual of exchange between Union and Confederate soldiers.

Soldiers interacted with the enemy in many different ways. Fraternization first began when soldiers hurled stones back and forth at one another. Soon throwing stones turned into conversation as men shouted back and forth at one another or joined in singing songs of the enemy's band. Music was often the key that opened the door to 
acquaintance and provided the basis for continuing association. ${ }^{33}$ In one example, Edward L. Heinichen, a civilian and southern sympathizer, stated, "Perhaps our band would play ‘Home Sweet Home’ when it would likely be answered by ‘The Mocking Bird.”’34 Jokes also served as icebreakers. For example, Private Jacob L. Betchel described, "The Rebels were doing picket duty on the opposite side, which is only a stone's throw across, we could talk to each other, and a great many good jokes are cracked between them and us, songs were sung of all kinds.” ${ }^{35}$ One of the most famously recorded jokes of the time was the Confederate slogan, "It will be a hard road to Richmond with a Longstreet to travel, two Hills to climb, and a Stonewall to get over.”36 Another less famous joke, but equally amusing, came from Mary S. Hill a civilian of Fredericksburg. Hill states, "We went the next day to the Rappahannock, where the men of the $6^{\text {th }}$ Louisiana were on picket; yanks on the other side. While on the river watching the 'Tiger' floating over, I heard the following conversation: Yank, 'Did you see our balloon?' (They had sent up three.) 'Why didn’t you send one up?' 'We do, but it wants no gas. It is called Jeb Stuart, and knows where you are, and how many."”37 This joke illustrated the friendly nature and commonalities between the soldiers. Men would interact by conversation and joking, but this dialogue reveals a distinct discourse associated with soldier culture.

Whether the soldiers conversed by yelling across the river or by crossing into enemy lines, there was a distinct vernacular nature to the conversation. The fraternization on the Rappahannock happened in a jovial and respectful manner. Soldiers referred to each other as "Billy" and "Johnny". They used slang to joke about "Jeff Davis" and “Abe Lincoln”. Each side was respectful of one another's culture, seen when Northern 
soldiers joined in the singing of Southern songs like "Dixie” and "Bonnie Blue Flag”. In one example, Private David Lilley $2^{\text {nd }}$ DE noted, “The Rebs ask us if we don’t want some cotton, and we say no we have got plenty of wool.”38 This joke had a racial twist to it because "wool” was often a word used to describe African-American hair. Similar to this example, soldiers often highlighted stereotypes of the armies such as the Union soldiers warm coats and good rations. For example, Wyman White of the Second US Sharpshooter's described the Confederate pickets when he stated, “They kept asking us 'Say Yank, When are you all coming over here with you eight days rations? We are awfully hungry over here!"”39 Southerners were known for their jokes and sectional slurs while northerners were known for shouting humorous vulgarities. ${ }^{40}$ The nature of these conversations indicates a deeper awareness of one another. Commonalities between soldiers highlighted the deep issues that had sparked the conflict, camp boredom, and war weariness as the struggle dragged on interminably. ${ }^{41}$ For many of these men, this was their first interaction with someone from the opposite side. These men had only hearsay and stereotypical descriptions about what men on the other side were like. Therefore, many soldiers became curious about the enemy and wanted to learn more about them. Dialogue and jokes soon turned into trade and visitations.

Arguably, for historians, the most memorable scene of fraternization on the Rappahannock was the trade of coffee and tobacco. Other than curiosity, the need for these commodities was the most common attraction to fraternization. Confederates longed for coffee and Federals longed for tobacco to smoke, so soldiers constructed sailboats in order to trade these items. Due to naval blockades that prevented trade between the North and South, soldiers saw picket duty as a way to obtain these items 
without charge. Private James J. Reeves of the $24^{\text {th }}$ New Jersey Infantry stated, “The Rebels were exceedingly communicative and cordial, and anxious to exchange the weed for the more wholesome luxuries of hardtack and coffee.”42 On the opposite side of river, the Confederates had a similar type of experience. As described by Private Henry P. Garrison of the $18^{\text {th }}$ Mississippi Infantry in a letter to his wife, "The boys told me that they were having a good time with the Yankees while on picket-trading with them every day, swapping tobacco for coffee." 43 Sailboats were constructed to carry these items over and were named something such as "Billy and Johnny” or "The Monitor and The Merrimack”, all in good fun. The construction of toy sailboats and the trade of rare commodities, although against orders, were relatively harmless. What typically followed the coffee and tobacco exchange drew much more attention from the officers.

Once soldiers gained a sense of trust and grew comfortable trading with one another, they began to trade newspapers. As the trade of goods and newspapers continued throughout the winter of 1863, both sides passed ordinances against fraternization. To see men who had tried to annihilate one another mixing freely was an odd and, to officers, disconcerting sight. ${ }^{44}$ When General Hooker took over control of the Army, he instituted laws against fraternization. Hooker feared the press, both as a means of passing useful information to the enemy and as a source of discontent among his own troops. Thus, Hooker barred irresponsible journalists from his camp, prohibited the distribution of disloyal newspapers, and required that all civilian news reporters must go through the provost marshal. ${ }^{45}$ General Lee issued two orders: one was to destroy all boats found anywhere and the second was, to arrest any Yankee found in Confederate lines. $^{46}$ Officers would attempt to catch men who fraternized by ordering roll call in the 
middle of the day. ${ }^{47}$ Commanders knew that fraternization was a risky action for several reasons. First, when soldiers traded newspapers or spoke of plans, the army's movements could leak to the enemy. In addition, newspapers contained details on public opinion and the state of the army, which were best if kept out of enemy hands.

Enemy papers were a hot commodity for Union and Confederate soldiers alike. Despite strict penalties against it, soldiers continued to exchange newspapers. James Pratt of the $11^{\text {th }}$ US Infantry stated, "I walked out and had a pleasant conversation. Proposed an exchange of orders. But infractions were winked at. I bottled up the latest Washington paper and threw it over. The Virginian swam out, caught it in his teeth and returned. He sat on a log with a dozen fellow readers and was enjoying the account of the active sympathy of their brothers, the copperheads of the North." ${ }^{48}$ Officers felt that newspapers were a threat to the Army's safety and security, but what the culture of alienation revealed is that soldiers were more likely to read papers and hide them from their officers, then turn papers or their enemy in. Egbert M. Rogers of the US Signal Corps wrote in a letter, “On the banks of the river, just below the city, we have a signal station. Being down there, the other morning, I observed what appeared to be a shirt-tall stretched between two sticks, which were attached to a log of wood, floating in the middle of the river. There was a 'packet' I found to be loaded with mail. 'On deck', we found a Charleston paper, The Richmond Examiner, and a couple of other papers, all neatly folded and in perfect condition; accompanied with the request 'Please send us the latest you have’. Accordingly a N.Y. Herald, a Philadelphia Enquirer, and a Harper’s Weekly, and another paper were duly folded and placed on board and the packet's sail trimmed and turned for 'Secessia' again.”49 The trade of newspapers between enemies 
illustrates a commonality among the soldiers. Both sides wanted to hear what their enemy country thought of them. However, the high command of each army saw risks involved in allowing papers to pass so easily through enemy lines. Despite ordinances against sailboats, soldiers continued to send commodities and newspapers to their enemy in exchange for coveted goods.

Men would not only risk consequences of their commanders, but also physically risked their lives in the attempt to cross the river. The Rappahannock River was very deep in the middle, so for men who tried to swim or build boats the current took them downstream or even pulled them under. For example, William Buck of the $45^{\text {th }} \mathrm{PA}$ stated, "Friday January $9^{\text {th }}, 1863$ on return from enemy lines, the boat sank and two of our men drown in the river." ${ }^{50}$ Men risked their lives if they chose to fraternize. Why would these men continue to disregard orders and risk their lives to trade with the enemy? This ritual of exchange that evolved on the Rappahannock reveals a culture of alienation and dissent within the ranks of Civil War soldiers.

What began as shouts and jokes, evolved into a trade network, but fraternization evolved into something further. The same culture that drove men to fraternize developed further into a culture shared between enemies. Through fraternization, these men realized that not only did their comrades suffer from army life but also their enemies felt the same type of alienation. Both Union and Confederate soldiers would venture across the river to meet personally with their enemy. The permeability of the river not only allowed for the boats to cross, but for men themselves to cross. Men would sail or swim across the river and spend significant amounts of time within enemy lines eating, drinking, and talking. H.P. Garrison, a Confederate officer stated, "Has frequent intercourse with the 
Yankee Officers, one would hardly think there is enmity between us. We drink brandy. They all express themselves as tired of the war and they wish that we may soon be able to take a drink together.” Garrison's conclusion about his own relation to the enemy stands as an example for what other soldiers felt after speaking with men on the opposite side. Soldiers who shouted jokes and traded, felt a common sense of friendliness and empathy between one another, but once these men crossed the river and shared stories of home and feelings about the war, new conclusions and discoveries about one another developed. For most of these men, they had never seen a "Billy Yank” or a "Johnny Reb”, but as products of political propaganda, these men had preconceived stereotypes. Fraternization shattered these stereotypes when these men realized that their enemy had more in common with them then they had thought. The initial draws of curiosity, boredom, and for economic goods indicated why men chose to fraternize. These examples were at the very core of the culture of alienation because they served as outlets for dissent, which in turn opened the door to more significant types of fraternization such as dialogue and visitation. After these men felt comfortable with one another, the choice to interact and converse with each other took on a new level of interaction and illuminated a deeper meaning to fraternization. The conversations these men had with one another reveal why men took risks, why they dissented against higher authority, and most importantly provide insight into the common soldiers’ notion of masculinity and brotherhood. 


\section{Chapter II: Analyzing Beyond the Ritual of Exchange}

Between the months of December 1862 and April 1863, soldiers wrote about their experience fraternizing with the enemy. Within these intimate letters, numerous soldiers revealed their interactions with the enemy and shared similar opinions about the war. Francis Strickland, a dejected Union soldier wrote, “A rebel picket stayed 2-3 hours. He said he was sick of the war and wished it ended. We would bring Lincoln and they would bring Jeff Davis and meet in the river and let them fight it out and the soldiers go home.” Several variations of this quotation are found in the letters and diaries of soldiers who served on picket duty during the winter of 1862-63. Private Strickland's dejection in this quotation represents the culture of alienation. For most of these soldiers, this was the first time they stood face to face with a "Billy" or a "Johnny". After the bloodshed weeks earlier at Fredericksburg, one would think malice and hatred would have kept these men from meeting, let alone empathizing with one another. These ambiguous interactions are a key moment in Civil War history where soldiers on both sides experience a unique culture of alienation. The culture of alienation is analyzed by looking at who these men were and how army life and the failure at Fredericksburg led them to reclaim their manhood. Since the culture was both a cause and effect of fraternization, the analysis is two-fold. First, who were these men and how did their embodiment of nineteenth century ideologies develop into a culture of alienation? One must look at the pre-war society where these men were influenced by virtues of masculinity, independence, selfsufficiency, and political participation. This chapter strives to analyze how was challenged these notions as well as restructured them. The second goal of the chapter is 
to analyze how fraternization only cemented this view. The commonalities these men shared resulted in a mutual understanding of the rigors of army life. Chapter 1 discussed the ways soldiers fraternized, but this chapter will analyze who these men were, why they fraternized, and how fraternization serves as an outlet for alienated men in search of their independence.

Fraternization between Union and Confederate soldiers demonstrates the mutual disillusionment at this point of the Civil War. The culture revealed in the conversation between enemies shows that both Union and Confederate soldiers could relate to one another through common grievances. Even though Union soldiers had more reasons to be anxious such as the failure of upper command and lack of leadership, Confederate soldiers understood the boys in blue through a common culture of alienation and suffering. The ritual of exchange on the Rappahannock River developed because of the nineteenth century virtues and fraternity these men embodied. Thus amidst the bloodshed, enriched in ideologies of prewar society and the seasoning of battle, these men looked beyond the brutality and found a common bond between one another. Therefore, first one must investigate how prewar ideologies of independence and freedom shaped soldiers' notions of manhood.

The Civil War soldier who was on picket duty that winter, whether Union or Confederate, had been influenced by political propaganda. These third generation Americans came of age during the impending sectional crisis. They cherished their right to vote as a symbol of their manhood. They read newspapers and listened to their fathers, friends, and communities lecture about politics as part of their everyday routine. The birth of a Republican Government, the spread of market economies, and the growth of a 
middle class all led to an economic and political life based on the free play of individual interests. ${ }^{51}$ However, men from the North rarely encountered men from the South and vice versa. These men only had newspapers and politicians that created a picture of what a man from the opposite section believed in and fought for in their own mind. What possibly could a non-slaveholding small farmer from Georgia have in common with a factory worker from Boston? The biases and prejudices from very emotional and angered politicians of the time littered the newspapers and meetings that these men witnessed. A "Johnny" or "Yank" had nothing in common with one another. This was a very common opinion of men on both sides. Nevertheless, fraternization changed that opinion in some ways. These men learned they had more in common than they thought.

Most northern Civil War soldiers were products of a culture of benevolence, while many southerners were part of a culture of hospitality, which are directly linked to prewar fraternal orders, and the rhetoric of brotherhood. Especially for Union soldiers, prewar participation in societies of brother-hood and fraternal organizations played a role in their choice to fraternize. In mid-nineteenth century America, fraternal ritual was not only widespread, but chiefly a phenomenon of the middle classes. ${ }^{52}$ During the $18^{\text {th }}$ century, fraternal orders were dedicated to ideals of bourgeoisie class but as that class grew in the $19^{\text {th }}$ century, so did lodge membership. Created to establish cross-class membership of fraternal societies, Freemason lodges established bonds between workers and employers removed from the practical conflicts of everyday work life. Through connections built in local lodges and in capital cities, Masons created a network of trust, friendship, and communication that facilitated political activity. Fraternal rituals served 
to establish male identity. However, as the sectional conflict grew and divided the nation, the lodges began to divide as well.

Communications between lodges showed dedication to fraternal manhood and individualism but were not able to avoid the conflicting ideologies that plagued the larger nation. Many lodges quarreled over whether the lodge should promote industrialism or artisanship labor. Lodges in the Border States argued over the morality of slavery and the significance of slave labor. There ties were not always strong enough to overcome personal and factional rivalry, let alone deep chasms between different parties and their leaders. In addition, lodges divided because in the South middle-class values made comparatively little headway because of competing class interests were diminished by dedication to maintaining white hegemony. Fraternal ties opened connections and pathways of communication; they did not determine the messages of the results. Therefore, prewar fraternal orders did not prevent the onset of war nor keep these soldiers from fulfilling their duty, but they did affect how men respected their enemy during peacetime. Historian Mark Carnes states, “The rise of fraternal ritual is evidence of man's ability to create cultural forms to mediate the demands of society". ${ }^{3}$ The demands of society in prewar antebellum America are comparable to the hardships and struggles men experienced in the ranks. Thus, men recreated these cultural forms to alleviate the stress of battle and army life. The most obvious way these soldiers extended the culture of alienation through fraternalism was through the exchange of coveted goods. For example, Egbert Rogers recalled, “A few of our men went over to the enemy line and were given corn break, whiskey, tobacco, and cigars." ${ }^{54}$ Soldiers on either side gave better rations to the enemy who visited during picket duty than to their own men. 
Because the Confederates gave their enemy these luxuries while their own men starved in the city of Fredericksburg, a culture of hospitality existed. An intrinsic sense of fraternity allowed for the hospitality shown by these Confederate soldiers.

Fraternization was by no means a demasculization of the soldier, but it was a return to the private sphere, marked by comfort, commodities, and brother-hood; an escape from the public sphere full of blood, dying, and death. Quite possibly the most common characteristic that linked these soldiers is the shared experience of suffering. In the most simple of terms, the trading of coffee and tobacco demonstrates how men lacked basic goods and risked their lives to obtain those goods. The year of 1862 was the bloodiest year of the war thus far and it was the first year of the war for many soldiers. In addition, the winter of 1862-1863 was the first winter that many soldiers experienced the harsh realities of camp life and exposed themselves to the physical hardships of the weather. Therefore, young soldiers away from home not only became homesick, but also missed the comfort of women, or in other words, the private sphere. Masonic rhetoric portrayed the lodge as a separate sphere of refreshment that helped create a fundamental model of masculinity in which men, rather than being strictly community members, private beings, or alternatively, citizens, participated by turns in both a peaceful private sphere and an uncertain, troublesome public world. ${ }^{55}$ Sometimes fraternization and random acts of kindness were through common membership in fraternal organizations, such as the Masonic Order. ${ }^{56}$ Drills, marching, and fighting were all aspects of the public sphere were soldiers tested their manhood similar to what these men did in life before the war. The fraternal organizations before the war were an escape from the public sphere, similar to how soldiers saw fraternization as part of the private sphere during the war. 
The Civil War soldier’s participation in fraternal orders often emphasized a culture of individualism. These soldiers were products of the self-made man generation. These men come to war with a preconceived notion about who their enemies were, but an unconscious understanding about what they fought for. Men, both North and South, took their identity and social status from their own achievements and not from the accident of their birth. ${ }^{57}$ Fraternalism promoted individualism and mobility, while at the same time idealizing mutuality and brotherhood, and contained a critique of the changing social order, which helped improve the worst failures of the new social system. ${ }^{58}$ A man's sense of individualism is defined through their characteristics of ambition, rivalry, and aggression. These men came from many different occupations: farmers, merchants, professionals, artisans, laborers, etc. No matter which way they made a living, these men experienced competition in the capitalist economy on a regular basis. Superiority and dominance was a virtue to the nineteenth century man, so they embraced the opportunity to exhibit their manhood through bravery and honor as a soldier. The reverse side of virtue was failure. The fear of failure was intense among men fighting in the Civil War. Failure was a sign of poor character. ${ }^{59}$

Virtue and failure literally came full circle for one soldier who decided to disobey orders and fraternized at Banks’ Ford on the Rappahannock. According to LieutenantColonel Hilary Herbert of the $8^{\text {th }}$ Alabama:

One day...the writer was visiting the picket line. Just as the writer rode out of the bushes below up to the post, a Federal soldier with trousers off was within ten feet of the bank of our side. The soldier halted. Come on! 
said I. 'I won’t come,' said he, 'unless you will let me go back. Colonel, this is not fair. These men told me I could come over and go back.' 'Yes.' was the reply, but you knew it was against orders, and I know you are violating orders on your side. There is no way to stop this except to enforce orders, and you are my prisoner. 'Colonel, shoot me if you want to, but for God's sake don’t take me prisoner. I have only been in this army for six months. I have never been in battle. If I am taken prisoner under these circumstances, my character at home will be ruined. It will always be said I deserted.’ The appeal was too much for me. He was sent back with an admonition to him and his comrades that he was the last man that would ever be released... ${ }^{60}$

Colonel Herbert's experience with the Union soldier indicates a commonality between himself and the enemy. Thus, Civil War soldiers both North and South had a commonality between their enemies: they rather lose by trying than win as a coward.

Finally, Civil War soldiers fought to uphold their gender roles of masculinity and manhood. $19^{\text {th }}$ century Americans were products of the ideology of separate spheres. While men were part of the public sphere and dealt with politics, labor, and money, women were part of the private sphere that controlled the child rearing and domestic labor. When men left home to enlist in the Army, men of both the North and the South faced the same challenge: to uphold their gender-role. Many of these men came to the city of Fredericksburg in early December 1862 where the courage and honor that embodied their manhood stretched beyond what anyone thought possible. What drove these men to risk their lives for the enemy that a few weeks earlier they were trying to 
destroy? Civil War soldiers shared values of manhood, brother-hood, and self-identity. Therefore, when their officers threaten these ideals, fraternization becomes an outlet for dissent.

Most of all soldiers wanted to display their manhood through the virtue of courage. Both Union and Confederate soldiers fought to resist deemed as a failure or a coward. Fredericksburg was an ultimate display of courage even when the Union Army failed to take the heights. Soldiers fought for the ideals of their forefathers and to protect their homes, families, and communities. Southern soldiers thought Yankees fought to free the slaves and Union soldiers thought the Rebels fought to keep their slaves. Not until these men met on the Rappahannock did these stereotypes diminish. When men shared their motives to fight, they realized their enemy had many similar motives. Both Union and Confederate soldiers fought for their home, independence, family, community, and the unit. However, the same motives that drove soldiers to fight, drove them to pick up the rifle in the spring of 1863 and continue to fight despite their newfound commonalities with their enemy.

Since pre-war virtues helped these men come together, the second part of this chapter intends to analyze how fraternization cemented the culture of alienation since soldiers realized it existed in enemy ranks as well. Highlighted through fraternization were these ideological motives and values that soldiers brought with them to war. Nevertheless, fraternization revealed commonalities subsisted among enemies. The first example is at the heart of the culture of alienation: discontent with the officers. During the Battle of Fredericksburg, most of these ideologies that drove men to enlist and fight were tested. Because of this test, soldiers were more reluctant to fraternize and found 
many commonalities upon doing so. On December $13^{\text {th }}, 1862$ seven divisions of men were ordered one by one over a six hour period to proceed over almost a mile of open ground towards almost an entire corps of Confederates holding heights and protected by a stonewall. These men not only watched their comrades' fall before them, but also saw men coming back into the town wounded and crippled as they crossed the pontoon bridges. These soldiers immediately met artillery and crossed the field stepping on the bodies of the wounded. The Union Army could not help but wonder why they continued the charge as cannon fodder when it was already obvious that the attack was doomed. The bloodshed and loss at the Battle of Fredericksburg cause many soldiers to distrust their commanders and rethink their reasons for fighting the war. Soldiers had many other reasons to dislike their commanders. Some commanders used coercion by threatening to shoot men if they did not fight. Commanders also were very harsh at drilling and expected men who had never picked up a rifle to perform as regular soldiers. Many soldiers honored General McClellan and felt no other general could live up to his command. For example, a letter from the Rappahannock stated, “As long as military and political jealousy is allowed, full sway of the rebellion will never be put down. Never! Not one of our generals that have begun to make themselves popular and shown that they were men of the times.”61 Common soldiers also were angry with their commanders who drank and treated them as children with petty punishments and senseless enforcement regulations. ${ }^{62}$ Due to this type of treatment, soldiers disrespected their officers and thus were quick to disobey them for the opportunity to fraternize and tell the enemy that they are sick of this fight for the officers. 
The most significant way in which enemies could relate to one another was as victims of uncaring military elite. Shared in enemy discourse was the alienation by the officers. At a time when bravery and honor were the most important characteristics among men, many were not afraid to admit their distaste and frustrations with the war. The New York Herald reported, "On the assurance of our men that they would not be detained as prisoners, a party of the enemy pickets crossed the river yesterday, and mingled in a friendly manner with our troops. They expressed themselves as heartily sick of the war, and proposed as a means of amicable settlement that the rebel army should hang Yancey, and that we should do the same for Horace Greeley, and then hands and call it square. Another proposition was that the soldiers of both armies bring their officers up to the front, and let them fight it out among themselves, while their men looked on as judges, and abided the result. After a prolonged visit they departed, to be in time for their role call." ${ }^{63}$ Despite differences as to why men in the blue and gray fought the war, some men who fraternized learned they had more in common with the enemy than the commanders did on their own side. One Michigan Sergeant stated, "A perfect feeling exists between the privates of both of the two armies. They are quite as sick of this inhumane, wholesale manslaughter as we are. If a vote of those composing the rank and file of both armies could settle this, there would be no more battles." ${ }^{64}$ The Sergeant's experience with the enemy shows the culture of alienation. What a soldier and his enemy fought for was their chance to prove their manhood and not viewed as a coward or a failure. Fraternization gave these men the opportunity to realize that their enemy was fighting for the same virtue as them. This realization leads to a significant distance between the common Civil War soldier and their officers. 
Despite the Confederate victory and the reverence for General Lee, Jackson, and Longstreet to name a few, one could make an argument that this war could be described as a "Rich Man’s War, Poor Man’s Fight” due to the expressions of the soldiers on both sides. Even though Confederate soldiers' rarely criticized their generals in their letters and diaries, they were not content with army life. For example, Private Dobbins of the $16^{\text {th }}$ Mississippi stated, “Our food has been pretty bad lately. For tobacco, out pickets trade coffee. We have become friendly with Yankee pickets. We all agree that we've had enough of the war and are ready to go home. Considerable number of fights in camp recently. We are bored, bored, bored.”65 At first glance, this Private Dobbins’s experience illuminated the hardship and boredom of army life during the winter of 1863. These common emotions by enemies revealed that in some instances there was more understanding between privates horizontally across lines rather than vertically throughout ranks of the same army. This reaction signified soldiers' distaste for the officers who ordered them into battle as cannon fodder. Soldiers complained that their officers were either drunk or were only interested in self-promotion. George Rable describes, "Recognizing a common humanity implicitly made resuming the slaughter more difficult, and indeed the reason for the officers' caution about such truces soon became apparent. Only the generals really wanted the war to continue, some enlisted men maintained. The privates could easily settle all outstanding differences among themselves." ${ }^{\text {66 }}$ This culture of alienation was a reason as to why soldiers would disobey their officers and chose to fraternize. Soldiers hid newspapers they obtained from the enemy. In one instance, a Union soldier obtained a letter from a Confederate to mail to his sweetheart in the North and the soldier kept the letter hidden from his commander. Union Soldier was 
asked to mail a letter and recalled, "The young soldier from the Washington Artillery wrote to his sweetheart at Sing Sing, NY in which he tells her of his devotion to his adopted country- the confederate states- and tells her that next to it he holds her most dear, but offers to release her from all obligations to him if she desires it, trusting, however that her love for him will prompt her to give up all - even the hated government under which she lives, for him.”67 The letter shows a stronger bond to his country than the love for his woman; a commonality for a man on either side. Since this soldier empathized with the enemy over his commander, a shared sense of empathy for the common soldier is apparent. Many of the men who fraternized believed that the only thing that kept the war going was the greed of the officers who will wait until they make enough money and then resign. ${ }^{68}$ This type of sentiment was extremely common for the Union Army at this time in the war and their Confederate brethren related.

Politicians and their policies were also a large factor that disregarded the opinions of these soldiers, most importantly through the terms of the Emancipation Proclamation. While these men sat on the banks of the Rappahannock on picket duty, the Emancipation Proclamation was issued on January 1, 1863. Historian Chandra Manning ${ }^{69}$ describes the shift in the relationship between ending slavery and the purpose of the war as, "After nearly two years of observing slavery, interacting with slaves, and fighting a horrible war, the Union rank and file now recognized slavery as a much more insidious cancer, embedded in the very spine and sinew of the nation." ${ }^{70}$ Most felt that Lincoln's decision to attack slavery changed the goal of the war and negated his promise that the war's purpose was to save the Union and not to free the slaves. The fight for the Union united men; but the fight against slavery divided the men. Men had campfire arguments about 
slavery. James McPherson states, "It was no accident that these heated discussions took place during the winter of 1862-63. The Emancipation Proclamation had given a sharper edge to the controversy. Soldiers who had advocated an anti-slavery war from the beginning naturally welcomed the Proclamation." ${ }^{71}$ Some men felt that the Emancipation Proclamation was beneficial in the sense that every slave freed would hurt the capacity of the Confederacy to wage war. On the other hand, Democrat soldiers and men fighting from the Border States were pro-slavery. McPherson argues, "But plenty of soldiers believed that the Proclamation had changed the purpose of the war. They professed to feel betrayed. They were willing to risk their lives for Union, they said, but not for black freedom." ${ }^{72}$ For many soldiers, if the removal of General McClellan, the defeat at Fredericksburg, and the Mud March was not enough to cause disillusionment, the Emancipation Proclamation was essentially the straw that broke the camel's back. The Proclamation served as another source of frustration for a percentage of soldiers in the Army of the Potomac, especially those from the border states of Kentucky and Maryland. McPherson states, "For several months during the winter of 1862-63, those who expressed hostility to emancipation seemed to outnumber those who supported it. And morale certainly declined." ${ }^{73}$ However, historian Chandra Manning argues that soldiers’ reactions to the Proclamation were not as negative as one would assume. Manning states, "To most Union soldiers, emancipation and declining morale were distinct phenomenon, not two halves of a cause-and-effect relationship, Union troops themselves attributed their sagging morale mainly (but not solely) to military factors." ${ }^{, 74}$ Whether or not soldiers were in favor of the Emancipation or not, Manning argues that at this point in the war the Army of the Potomac felt as if it had been "put through the wringer." 75 If these 
men chose to stay, these frustrations with President Lincoln and politicians convinced some of these men to fraternize. Yet again, soldiers were angered with politicians and generals but chose to stay the course rather then called a coward. However, other ways to dissent prove to be effective as well.

A significant part of the culture of alienation was the Civil War soldier's tendency to violate military authority. Soldiers shed hatred towards their enemies due to months of hardship and the conviction that the common soldiers of both sides were victims of political machinations. ${ }^{76}$ Dissent was another way soldiers would exhibit frustrations against officers and fraternization was one of the most common outlets. Fraternization was a form of subtle dissent. The majority of enlisted men during the Civil War were citizen soldiers. Common soldiers were often long time acquaintances of their officers and saw them more like friends rather than superiors. James Robertson states, "Discipline was never tight enough to keep soldiers from doing something which they believed was justified at a particular time." ${ }^{77}$ Disrespect for authority was the first and most prevalent offense committed by both sides. When discipline tightened, soldiers became unhappy. Officers became stricter about absences, furloughs, and cowardice. On the Union side, General Joseph Hooker tightened up discipline in order to realign the army after Burnside’s defeat. Private Morton stated, “ ‘Fighting Joe Hooker’ is trying to get the army disciplined again the same as it was last winter under General McClellan, a thing which I think it is impossible for him to perform." ${ }^{78}$ Union soldiers deserted by the thousands because of the discontent with generals and the bloodshed at Fredericksburg. After the battle, Wyman White stated, "We have thrown ourselves against impregnable fortifications until northern blood ran down and colored the muddy water of the 
Rappahannock. And what had been gained? Simply nothing...,79 Despite victory at Fredericksburg, the Confederacy also experienced an increase in discipline. The Confederacy enacted conscription in April of 1862, so many of the men who picketed on the Rappahannock were not volunteers and forced into the ranks. ${ }^{80}$ In addition, Confederate soldiers deserted after their homes had been raided and destroyed and felt a need to return home. On both sides, the constraints on men due to the boost in discipline not only angered these men but also made them apathetic to many ordinances and regulations. Just because soldiers stayed the course and did not dissert did not mean they were pleased with their commanders or position in the Army.

Most of all, the inherent nature of a Civil War helped in the creation of this culture of alienation. In other American wars, enemies were of a different cultural background and it was more difficult to empathize with them. In some ways, it was easier to be malicious to enemies of a different race or culture due to the visual differences. In addition, since they spoke different languages, fraternization was difficult. However, during the American Civil War, enemies looked alike and spoke the same language. Many fought on opposite sides of their brothers and friends. The Buell brothers actually fought against one another at the battle of Fredericksburg and met across the Rappahannock during picket duty. Lieutenant-Colonel Hilary Herbert of the $8^{\text {th }}$ Alabama wrote, “While we were at Banks' Ford, David Buell, an enlisted man in the $8^{\text {th }}$ AL, born in New York State, visited his brother Seth, across the river, and afterwards told me of the conversation that ensued. Seth did not for a moment think of asking David to desert his colors, but was full of commiseration for the condition of his poor Confederate brother, subject to hunger, etc., all of which David patriotically and with 
some disregard of truth denied. But Seth was not to be put off, without doing something for his brother, and finally insisted on giving him a pair of 'big warm U.S. blankets.’”81 The Buells' experience supports the stereotype of the war being "brother versus brother." Most of all, both sides were products of a generation based on ideals from the expanding and growing nation founded in liberty. As historian James Robertson has observed, "Opposing Forces spoke the same language; they had the same likes and dislikes, the same backgrounds and cultures, the same roots in America's soil." ${ }^{82}$ Rhetoric of the American Revolution was a type of patriotism on both sides. Many soldiers fought to defend their homes and families primarily, while other issues such as slavery were secondary. Soldiers both North and South fought for a common cause, which they understood during conversation on the Rappahannock. Fraternization for these soldiers of the same descent, same American stock, and same ideas of self-interest combined with the conditions of camp, for many months, positioned very close to one another, only invited these interactions to develop into a common culture.

The several different reasons that alienated men in the ranks contributed to their need for an outlet to reclaim their manhood. From the most basic curiosity to the most intricate conversation, fraternization illuminated how and why Confederate and Union soldiers chose to risk their standing in the army for the enemy. The common Civil War soldier was disillusioned after the Battle of Fredericksburg and fraternization was a way to express frustrations and reclaim independence that was stifled by army life. Some men did not fraternize, but for those who did, it meant something different to everyone. For some men, it was a way to get a warm cup of coffee or tobacco while on the freezing river. For others it was a means to get a close look at a Billy or a Johnny. Some men saw 
it as a subtle form of resistance instead of running away. Whichever way these soldiers met the enemy, it all falls under the argument that Civil War soldiers chose to fraternize as a way to show their independence and in return related to one another through common characteristics of nineteenth century manhood. The ideologies these men embodied led them to fight but also to fraternize when the larger causes were overshadowed by defeat and despair. Upon meeting one another, enemy soldiers found many similarities between how they felt about the war and why they fought. However, the same ideals of honor and manhood that drove them to fight prevented them from deserting or revolting and led them to pick up the rifle and march ten miles west to a little known crossroads named Chancellorsville. 


\section{Chapter III: Fraternization and Reconciliation}

The culture of alienation was revisited throughout other times during the war and during the post-war period. Fraternization characterized through the exchange of goods, thoughts, and hopes for peace during the winter of 1863, ended when the grounds dried and Hooker's Army moved out. The armies that previously sat across a watery space as friends found themselves facing one another across a deadly space. The fraternization that took place during the winter did not keep men from picking up their rifle and moving on to fight. The same characteristics of manhood and honor that drove men to enlist compelled them to continue to fight. However, the fraternization during that winter would not be the only or the last time these men conversed with the enemy. After the Battle of Chancellorsville, before moving North, the Armies came back to the Rappahannock to guard the fords. Fraternization occurred again as men from North and South joined one another in the river for swimming parties. After the Battle of Gettysburg, during the Fall of 1863 the armies fraternized while in defenses during the Mine Run Campaign. However, these regiments included conscripts that had different motives than volunteers. During the Petersburg Campaign, soldiers lured each other with food and talked of peace while in the trenches during the last year of the war. Again, separate from Fredericksburg, this was two years later when the Confederate Army was in an extreme state of desperation. Therefore, the winter of 1862-1863 was not the only season of the war where fraternization took place, but it was a unique venue for the culture of alienation to develop. Fraternization was not unique to the soldiers on the Eastern Theatre; many experiences at Vicksburg and Mobile recorded accounts of 
fraternization. However, these accounts were market by malicious racial jokes.

Therefore, Fredericksburg was again unique because of the peaceful nature of the culture of exchange. Since fraternization occurred throughout the war when the armies were camped close together, after the war it became popular in media and literature. In the postwar world, fraternization served as an important tool among reconciliationists. Politicians and reporters sought accounts of friendliness among soldiers to demonstrate if enemies got along amidst the bloodshed, they should be able to get along during peacetime. Therefore, in order to understand fraternization on the Rappahannock from another angle, the memory of these interactions needs further investigation.

In the 1880 s and 1890s, reconciliation and fraternalism emerged as a dominant theme in veterans’ culture. Veterans' newspapers and magazines featured the mutual suffering and grievances experienced by men on both sides during the war. Soldiers were a symbol of reunion because of their dedication and heroism, regardless of which flag they fought under. Historian Nina Silber argues, "This romantic form of reunion, developed as veterans sought to brand the Civil War as a war of virility: an ultimate display of masculinity." 83 Both sides fought for the same ideals and endured large amounts of suffering. ${ }^{84}$ The same suffering men recalled after the war is similar to the emotions shared during fraternization on the Rappahannock. Some of the earliest Union veterans' narratives included tales of how the two sides “fraternized” with one another. Veterans also found commonalities in a rich man's war, poor fight. According to a Wisconsin veteran J.A. Watrous, "Veterans on both sides now had a common foe at the bar of memory: the arch-conspirators of 1860 and 1861, who precipitated the war, and were careful to avoid the battlefront." 85 The same culture of alienation that linked the 
common soldier together during the war, stood as reasons for reconciliation after the war. When soldiers fraternized on the Rappahannock, they discovered commonalities of suffering and alienation between one another. Reconciliationists used these same reasons in the postwar period. Therefore, the soldiers who fraternized on the Rappahannock and shared talks of peace were some of the first Reconciliationists. Watrous also stated, “All could have faith that the day is coming when the gray-haired men of the war of 1861-5 will meet and fraternize as soldiers, scarcely halting to ask each other whether they wore the blue or the gray.” ${ }^{86}$ Reconciliation between Civil War soldiers began long before Appomattox.

One of the most detailed accounts of the fraternization on the Rappahannock was by Private C. P. Walker of the $3^{\text {rd }}$ Alabama Regiment written in 1901 in a post war journal. Walker's account published in the Atlanta Journal described winter quarters camped in Fredericksburg. Walker wrote about dialogue shared with Yankee pickets and states:

I hollowed across the river 'Hello Yank!' The answer came: 'Hello Johnnie!’ Phil asked: ‘Have you got any coffee?’ Yank answered 'Not much.' 'Don’t you want some tobacco?' I asked. 'Yes’ said he, 'I will be very glad to get some, 'How can I get it?' I asked him if I swam across with some tobacco would he exchange with his coffee for some tobacco, and let me come back. He said he would if I would hurry as the officer of the day would soon be around. Phil ran, in the darkness to a sutler's tent, a quarter mile distant, secured five or six pounds of fine tobacco (He had no money but I didn’t ask how he got the tobacco.) We secured a slab 
about fifteen feet long and fastened the tobacco on two pegs driven at one end. I stripped heels for a propeller, I swan the river delivered my cargo, got ten pounds of nice ground coffee and returned in the same way. He is the nice part of my story. When I reached the opposite bank that Yank hauled me, almost frozen, out of the water, wrapped me up in his big blue coat and cape and laid me by his big fire until we made the exchange and fastened my coffee on the slab, talking like an old chum and play-fellow all the time. ${ }^{87}$

This interaction demonstrated a trade that several others experienced during the winter on the Rappahannock. However, even in the most eloquent diaries and letters, the level of description used does not compare to this account. This account holds no reservations about the dangers associated with crossing into enemy lines. Walker's story only described the friendliness and benevolence of his enemy. There is no doubt that those who traded and conversed did so in a convivial manner, but this account seems embellished with detail and optimism. Walker's statements, written forty years after the war, made it hard to believe that intricate details about the dialogue and the length of the boat were so easily remembered. This account, coming from a southern journal, had a reconciliationist slant.

The next part of the article that stands out is the most moving account of fraternization seen in this research study. Walker wrote, "The war could have closed then and there if the contending armies had heard our conversation. When he had made ready for my departure he placed in the sack of coffee a pocketknife with fork; spoon, corkscrew, hook, toothpick, and gimlet attachments, helped me into the cold river, 
pushed me off and bade me goodbye. We mutually agreed that if ever we met in battle and recognized each other we would shoot some other man, and not each other. I am sorry that I did not learn his name and his command, but if he is alive and sees this communication, I shall be glad to hear from him.”88 This quote demonstrated the transition in the element of emotion from wartime to postwar sources. Although this account is not a lie, it goes into deeper remorse and shared suffering than any wartime account. Through their dialogue, Walker and his Yankee friend demonstrated the larger ideology of separate spheres and a culture of alienation. However, in no other account of fraternization was there such emotion shared between enemies. Walker's last comment about his hopes to hear from this man drives home the argument that the document had a bias from the reconciliationist. Walker's experience, among others, is an account that attempts to show that if soldiers showed such commonalities during the war, then forty years after the war friendship is even more possible.

Coupled with reconciliation literature about fraternization during the war, were actual postwar reunions of the Blue and Gray soldiers who fraternized as veterans, which marked a return to the culture of alienation. Reunions became very popular in the postwar period of the 1880s and into the new century. Places such as Gettysburg and Chickamauga and Chattanooga Battlefields hosted veterans' reunions. When these veterans spoke to one another, it was not about the causes or the outcome, but more about the shared experience of their sacrifice. Veterans felt they had more in common with one another, than from people who never experienced the war firsthand as they did. Veterans felt a sense of brotherhood because postwar politics and relations were orchestrated by those who did not fight. Just as these men felt ambiguity from the politicians and officers 
during the war, during the period of reconciliation veterans again felt alienated and confused about their place in society. Historian on Civil War Memory, David Blight ${ }^{89}$ claims at the first reunion of Gettysburg in 1887, "the members of both groups pitched tents on the very ground of their battle, shared stories, and exchanged hats and other mementos. A witness observed that it was hard to tell which was the Philadelphia Brigade and which Pickett's Division was."90 The interaction among veterans is a unique and private culture that mimicked the situation on the Rappahannock. These men turned away from the outside world of pressure and politics and looked inward to one another. At the reunion at Chickamauga and Chattanooga National Military Park in 1895, Union veteran Willard Warner stated, “Occasionally we hear a preacher, belated in being born too late for the fight, who makes war by speech or pen, or women, broom stick in hand, who show fight, but the soldiers of the two armies and the mass of our people are serenely at peace. It is not time we had ceased talking of the bloody chasm?"91 Just as these men felt alienated by armchair politicians and generals during the war, they were angry at those who continued to talk about the causes long after the war. Soldiers on the Rappahannock during the war and veterans at the reunions after the war who shared their thoughts empathized more with one another than with those at home. This sentiment of brotherhood is the same type of commonality that brought men together on the Rappahannock. Therefore, the juxtaposition between what men thought about the war and actually led to a return of the culture of alienation that continued long after the armies left Fredericksburg. 


\section{Conclusion}

Arguably, the winter of 1862-1863 was the worst of the war for the Army of the Potomac. Even though the Confederate Army’s morale was at a high point, the soldiers felt the full effect of war as they sat in the city of Fredericksburg cold and hungry. Fresh off a victory, the Confederate soldiers had faith in their Generals and in the spirit of their army, but saw the Union Army replenish its ranks. Therefore, Union and Confederate soldiers were disillusioned during the winter of 1862-63 because the war had no apparent end in sight. Thus, when army life and the outcome of Fredericksburg threatened the independence of the soldiers and the cause dwindled, these men had to resort to a new outlet to regain their manhood. When soldiers had the opportunity to talk with men on the opposite side, talks of peace and home were at the forefront of these conversations.

The truth is that the fraternization on the Rappahannock never changed the outcome of the war. Men shared stories and commodities, but after the exchange, men never chose to desert. There were limits to this shared set of values, beliefs, and practices that did not allow men to transcend military proscription of a certain conduct. The culture of alienation competed with values and practices that northern and southern men shared among men of their own region, but helped them realized that a divide existed between them. Soldiers thought deeply about the experience of fraternization and wrote about these thoughts in letters and diaries, but never did it affect them enough to forget their duty. The same courage and honor these men shared, was the same characteristic that drove them to continue the fight. The values men brought with them to war were modified by the bloodshed and experience of fraternization but still remained in the 
hearts and minds of most soldiers. Therefore, when the ground dried and the temperature rose in late April 1863, men on both sides picked up their rifle and continued to fight. Soldiers did unthinkable things and sustained more loss and bloodshed at the Battle of Chancellorsville in May 1863. The Battle of Chancellorsville was General Lee’s greatest victory and another devastating loss for the Army of the Potomac.

The winter of 1862-1863 was not the only time these armies would have the opportunity to fraternize. The Army of the Potomac would return to the Rappahannock after the Battle of Chancellorsville even more disillusioned then before. Union soldiers would continue to trade and host swimming parties with the Confederates until both armies moved northwards into Pennsylvania. Fraternization would continue for the next year during burial detail and at field hospitals during the Battles of Gettysburg, Wilderness, and Spotsylvania. The Army of the Potomac and the Army of Northern Virginia would not be situated in a position like the city of Fredericksburg and the Rappahannock River until the siege of Petersburg. In the summer of 1864, the situation was very different for the Confederates. The Union Army attempted to lure the hungry Confederates to their lines with corn. The Confederate and Union armies again related to one another through suffering. Therefore, fraternization occurred in several different times and areas during the Civil War. Thousands of soldiers while on picket duty or other missions would converse freely with the enemy. However, since fraternization was 'taboo' during the war, reconciliationists uncovered these interactions in the postwar era to encourage peace.

Fraternization would continue to be an activity of armies in America's wars that followed the Civil War. Most famously was the singing of 'Silent Night' in the trenches 
on the Western Front during World War I. However, no other war of American involvement saw the extent of fraternization as the Civil War did. As a park historian at Fredericksburg, I have the chance to give battlefield tours to several veterans of World War II, Korea, Vietnam, and even Iraq. After the tours, these men commented on their own combat experience in relation to fraternization. They often replied with the opinion that they could not relate to them or even approach them because of the language and cultural barriers, but they felt if it was another “American” across the way...they might think twice about it. The inherent nature of the Civil War allowed humanity to rise when the smoke cleared. The extent of fraternization on the Rappahannock River captured this unique nature of a civil war.

The analysis of soldier experience both ventures from the older scholarship of the common soldier while at the same time opens the door to new ways of thinking. Early historiography on fraternization acknowledges it happened and was able to happen on picket duty and for the purpose of economic goods. This scholarship identifies the cause of fraternization as boredom and lack of goods, which although true stops short of the larger analysis of soldier culture. Current historians analyze why men fought and this specific study of fraternization caters to that debate in several ways. First, fraternization shows the common soldier troubled by the hardships of army life but remains in rank for larger cause and unit cohesion through dissent. Secondly, the "sustained motivation" to fight is demonstrated through the characteristics of the culture of alienation. In other words, the soldiers' attempt to regain their manhood through fraternization helped these men to stay the course. Therefore, this study does not intend to revise older ways of 
thinking but add another level of depth and inquiry while also reinforcing the dominant line of scholarship in present historiography.

The investigation of fraternization on the Rappahannock also provides interpretive questions for new ways of thinking and opens the door to new scholarship on the common soldier. Through this research and exploration, the suffering and bloodshed caused a crisis at the ground level. For the common soldier their experience was not just an end of innocence, but a complete state of chaos at the very foundation of their belief system. While figures such as President Abraham Lincoln and General Robert E. Lee were able to see the larger picture, the common soldier was unable to see the larger purpose. The linear universe soldiers knew crumbled at the very core. The young men encountered an intellectual problem and felt confusion about the larger power in control. Therefore, soldiers were forced to restructure their world amidst the battlefield and camp life. One of these attempts is the culture of alienation associated with fraternization during the winter of 1862-63. Future scholarship can analyze other ways soldiers attempted to make sense of the world around them after their metaphysical world was shattered by the psychological, physical, and intellectual damage of war.

Even though fraternization did not cause an increase in desertion or end the war, these interactions are still significant in their development of a culture of alienation. The several layers of fraternization revealed that the encounters were not uniform but were unique and took on a life of their own. Fraternization on the Rappahannock was not just the stereotypical trade of coffee and tobacco, but stood for much more. The culture of alienation that existed at that point in the Civil War, both caused soldiers to fraternize and the culture itself developed further because what soldiers learned through fraternization. 
Soldiers came together and shared stories of what they had in common: their homes, women, virtues, and hardships. Through fraternization, soldiers learned that the culture of alienation existed in their enemy’s camp as well as their own. The culture of alienation illuminates the notion that frustrations with army life ran deeper than victory or defeat on the battlefield. What better way to look at a soldier's experience than that what he told his foe? This tiny moment in time serves as a window into the common soldier experience. 
${ }^{1}$ Bell Irvin Wiley, Life of Johnny Reb. Arguably, Wiley is the father of the "new military" history that directs attention away from the generals and to the majority of the participants: the common soldiers. Wiley focuses on the experience of the Confederate soldier through hardships in everyday life and in battle. Wiley shows the evolution of the Confederate experience from initial excitement and victory at the onset, to weariness and loss as the war dragged on. Life of Billy Yank. Again, Wiley uses letters and diaries to reconstruct history from the bottom up to explore the stories and experiences of the common soldiers. Wiley recreates what the Union soldier felt in camp and battle, how they made sense of the war, and how their experienced differed from the Confederates. Wiley argues that Union soldiers were not always sure why the fought, but it was not usually in part with larger political issues or emancipation.

${ }^{2}$ Bell Irvin Wiley. The Life of Billy Yank: The Common Soldier of the Union. Garden City, New York: Doubleday and Company, Inc. 1952, p. 351.

${ }^{3}$ Wiley, Life of Billy Yank, p. 351.

${ }^{4}$ Wiley, Life of Billy Yank, p. 351.

${ }^{5}$ James Robertson, The Blue and The Gray. Robertson's purpose is to provide a window into the common soldier experience through retracing soldier accounts in letter and diaries. Robertson's argument is that men were very descriptive writers about their experiences and were quick to criticize. His use of historiography on studies of $19^{\text {th }}$ century manhood is a similar approach used in this paper.

${ }^{6}$ George Rable, Fredericksburg! Fredericksburg! Rable argues that in order to gain a more complete understanding of the battle of Fredericksburg, his approach uncovers the experience of soldiers and their connections to larger social themes. Rable's "new military" historical approach to the Battle of Fredericksburg is the basis for his book as well as this study. Rable addresses fraternization on several accounts yet claims that although soldiers fraternized, even sociable Confederates sounded more confident. ${ }^{7}$ Morton Hayward to Francis Hayward. February 9, 1863, in Lewis Leigh Collection, U.S. Military History Institute, Carlisle Barracks, Pennsylvania.

${ }^{8}$ Wiley, Life of Billy Yank, p.355

${ }^{9}$ Gerald Linderman, Embattled Courage. Linderman studies the cultural aspects of the Civil War soldier to argue that stresses of battle reshaped the initial causes the drove men to fight into something different that drove men to sustain the war, most specifically courage; James McPherson, For Cause and Comrades. McPherson uses a large survey of letters and diaries of soldiers to investigate the motives for fighting. McPherson argues that a deep political ideology existed within the majority of men who knew quite clearly why they enlisted and continued to fight. McPherson argues directly with Linderman, asserting that soldiers did not become ideologically weary as the war continued on Historians tend to focus on larger issues such as the Emancipation Proclamation, General Hooker's appointment, and the political leaders on both sides, which often overshadow these conversations. However, James McPherson, Gerald Linderman, and Reid Mitchell have paved the way for studies of the common soldier on the battlefield and in camp. This study supports the argument of both McPherson and Linderman. In support of McPherson's argument, fraternization indicates that soldiers had a vivid understanding of why they fought through the stereotypes they shared with the enemy during shouting matches, jokes, and conversations. However, Linderman argues that in order to sustain the fight, seasoned soldiers acquired a different motivation based on unit cohesion and other factors. Fraternization proves Linderman's argument true because the dialogue shared during fraternization highlights a mutual relation in a culture of alienation. Specifically, soldiers cannot help but lose faith in the politicians and generals and turn to one another for empathy and support.; Reid Mitchell, Civil War Soldiers: Their Expectations and Their Experiences. Mitchell uses letters and diaries of soldiers not only to recreate their wartime experiences but to find the meaning of the Civil War. Mitchell focuses on the similarities and differences of northerners and southerners to answer questions such as why these men fought and what they thought about the war; Earl J. Hess, The Union Soldier in Battle. Through the study of soldier culture, Hess argues that courage, unit cohesion, and bravery are part of Civil War soldier motivation but even the bravest soldiers could shirk their combat duties without labeled a coward. This study will use similar methodological approaches to analyzing soldiers' letters and diaries in order to uncover larger meanings and a greater understanding of the soldier experience.

${ }^{10}$ James I. Robertson, Soldiers Blue and Gray. Columbia: University of South Carolina Press, 1998. p. 139.

${ }^{11}$ Anonymous. History of the First Regiment Minnesota Volunteer Infantry, 1861-1864. Stillwater, Minnesota: Easton \& Masterman Printers, 1916. pp. 283-284. 
${ }^{12}$ Thomas R.R. Cobb letter to wife November 27, 1862, in the T.R.R. Cobb Papers, University of Georgia.

${ }^{13}$ Jeff Toalson. Send Me a Pair of Old Boots and Kiss My Little Girls: The Civil War Letters of Richard and Mary Watkins, 1861-1865, $3^{\text {rd }}$ VA Cavalry. December 20, 1862. Iuniverse, Inc, 2009.

${ }^{14}$ George C. Rable. Fredericksburg! Fredericksburg! Chapel Hill: The University of North Carolina Press, 2002. pp. 33-34.

${ }^{15}$ Rable, Fredericksburg!, pp. 88-89.

${ }^{16}$ Rable, Fredericksburg!, p. 267.

${ }^{17}$ Rable, Fredericksburg!, p. 300.

${ }^{18}$ Rable, Fredericksburg!, p.288.

${ }^{19}$ Rable, Fredericksburg!, p. 393.

${ }^{20}$ Edward A. Pollard. Southern History of the War: The Second Year of the War. New York: Charles B.

Richardson, 1865. pp.195-196.

${ }^{21}$ Pollard, Southern History of the War,, pp.195-196.

${ }^{22}$ Rable, Fredericksburg!, p.393.

${ }^{23}$ Wyman White, "Burnside's Stick in the Mud” in Diary of Wyman White, Fredericksburg National

Military Park, Fredericksburg, Va. (hereafter cited as FNMP) p. 66.

${ }^{24}$ Rable, Fredericksburg!, pp. 422-423.

${ }^{25}$ Private Joel Molyneux to Wife, December 17, 1862, in Partridge Family Letters, Shippensburg, Pennsylvania.

${ }^{26}$ Walt Whitman. Walt Whitman's Civil War. Ed. Walter Lowenfels (New York: Knopf, 1961), pp. 35-39.

${ }^{27}$ Gary Gallagher, "The Yanks Have Had A Terrible Whipping: Confederates Evaluate the Battle of Fredericksburg" in, The Fredericksburg Campaign: Decision on the Rappahannock, ed. Gary Gallagher (Chapel Hill: The University of North Carolina Press, 1995), 118-119.

${ }^{28}$ Gallagher, The Fredericksburg Campaign, pp. 129-130

${ }^{29}$ Gallagher, The Fredericksburg Campaign, p. 131.

${ }^{30}$ Rable, Fredericksburg!, p. 405.

${ }^{31}$ Daniel E. Sutherland, Fredericksburg and Chancellorsville: The Dare Mark Campaign. Lincoln: University of Nebraska Press, 1998. pp. 81.

${ }^{32}$ A. Wilson Greene, "Morale, Maneuver, and Mud: The Army of the Potomac, December 16, 1862 January 26, 1863" in, The Fredericksburg Campaign: Decision on the Rappahannock, ed. Gary Gallagher (Chapel Hill: The University of North Carolina Press, 1995), pp. 190.

${ }^{33}$ Bell Irvin Wiley. The Life of Billy Yank: The Common Soldier of the Union. Garden City, New York: Doubleday and Company, Inc. 1952, pp. 178.

${ }^{34}$ Edward L. Heinichen to Anonymous, Winter 1862-1863, in Edward Heinichen Memoirs, FNMP.

35 Jacob L. Betchel to Candice Betchel, February 10, 1863, in Jacob Betchel Letters, Gettysburg National Military Park, Gettysburg, Pa.

${ }^{36}$ Betchel, Jacob Betchel Letters, February 10, 1863.

${ }^{37}$ Mary S. Hill to Anonymous, Winter 1862-1863, in A British Subjects Recollections of the Confederacy while a Visitor and Attendant in It's Hospitals and Camps (Baltimore: Trumbull Brothers, 1875.)

${ }^{38}$ David Lilley to Anonymous, November 28, 1862, in David Lilley Papers, FNMP.

${ }^{39}$ Wyman White, “Burnside's Stick in the Mud”, in Diary of Wyman White, FNMP, pp.66.

${ }^{40}$ Robertson, Soldiers Blue and Gray, pp. 139-144.

${ }^{41}$ Robertson, Soldiers Blue and Gray, p. 140.

42 James J. Reeves. History of the $24^{\text {th }}$ Regiment, New Jersey Volunteers. Camden: S. Chew, 1889. p. 30.

${ }^{43}$ Henry P. Garrison to Cousin, January 27, 1863, in H.P. Garrison Letters, ETRC, pg. 53.

${ }^{44}$ Rable, Fredericksburg!, p. 276.

${ }^{45}$ Sutherland, The Daremark Campaign, p. 101.

${ }^{46}$ W.A. Johnson. “Winter Quarters at Fredericksburg 1862-1863”. Atlanta Georgia Journal, November 30, 1901.

${ }^{47}$ William M. Abernathy, “The Confederate Memoir of William M. Abernathy,” Confederate Veteran [a publication of the Sons of Confederate Veterans], 2:17.

${ }^{48}$ James Pratt to Anonymous, June $5^{\text {th }}, 1863$, in The Soldier of Indiana in the War for the Union.

(Indianapolis: Merrill \& Co., 1864), FNMP, pp. 96-97

${ }^{49}$ Egbert M. Rogers to Anonymous, February $26^{\text {th }}, 1863$, in Egbert Rogers Papers, FNMP.

${ }^{50}$ William Buck to Anonymous, January $12^{\text {th }}$, 1863, in Buck Family Papers, FNMP. 
${ }^{51}$ E. Anthony Rotundo. American Manhood: Transformations in Masculinity from the Revolution to the Modern Era. Chicago: University of Chicago Press, 1990.

${ }^{52}$ Mark C. Carnes and Clyde Griffen. Meanings for Manhood: Construction of Masculinity in Victorian America. Chicago: Chicago University Press, 1990. p. 39

${ }^{53}$ Mark C. Carnes, Secret Ritual and Manhood in Victorian American. New Haven: Yale University Press, 1989. pp. 146.

${ }^{54}$ Egbert M. Rogers to Anonymous, February 26 ${ }^{\text {th }}$, 1863, in Egbert Rogers Papers, FNMP.

${ }^{55}$ Carnes and Griffen, p. 260.

${ }^{56}$ Wiley, Life of Billy Yank, pp. 357.

${ }^{57}$ Rotundo, American Manhood,, p.3.

${ }^{58}$ Carnes, Secret Ritual, pp. 83.

${ }^{59}$ Rotundo, American Manhood, pp.178-185.

${ }^{60}$ Noel G. Harrison, Chancellorsville Battlefield Sites. $1^{\text {st }}$ Edition. Pp. 200.

61 "New England and McClellan”. NY Observer and Chronicle. February 19, 1863; 41, 8; APS Online; p. 61

${ }^{62}$ James M. McPherson. For Cause and Comrades: Why Men Fought in The Civil War. New York: Oxford University Press, 1998. pp. 54-58.

${ }^{63}$ The New York Herald. The Army of the Potomac: Our White Oak Church Correspondence. 1/1/1863. West Virginia University Databases.

${ }^{64}$ Sutherland, The Daremark Campaign, p. 81.

${ }^{65}$ Private Dobbins, January 14-15, 1863, in Grandfather's Journal, published 1988, FNMP.

${ }^{66}$ Rable, Fredericksburg!, p. 276.

${ }^{67}$ John L. Street to Anonymous, March 16, 1863, in John Street Letters, FNMP.

${ }^{68}$ Reid Mitchell, Civil War Soldiers. New York: Viking Penguin, Inc., 1998. p. 38

${ }^{69}$ Historian Chandra Manning revises historiography of the soldier sentiment towards slavery in her book What This Cruel War Was Over. Recent scholars suggest soldiers were apathetic towards slavery and did not fight for slavery one way or the other. Manning argues that soldiers had very strong opinions on the system of slavery as both a inhumane system and as a political economy. Manning's research lends depth to fraternization showing that the Emancipation Proclamation caused attention and concern from the soldiers camped on the Rappahannock River in early 1863.

${ }^{70}$ Chandra Manning. What This Cruel War Was Over: Soldiers, Slavery, and The Civil War. New York: Alfred A. Knopf, 2007. p. 84-85.

${ }^{71}$ James McPherson. For Cause and Comrades: Why Men Fought in the Civil War. Oxford: Oxford University Press, 1997, P. 121

${ }_{73}^{72}$ McPherson, For Cause and Comrades,, p. 122.

${ }^{73}$ McPherson, For Cause and Comrades, p. 123.

${ }^{74}$ Manning, What This Cruel War Was Over, p. 87.

${ }^{75}$ Manning, What This Cruel War Was Over, p. 88.

${ }^{76}$ Wiley, Life of Billy Yank, p. 350.

${ }^{77}$ Robertson, Soldiers Blue and Gray, p. 123.

${ }^{78}$ Morton Hayward to Francis Hayward, February 9, 1863, in Lewis Leigh Collection, U.S. Military History Institute, Carlisle Barracks, Pennsylvania.

${ }^{79}$ Wyman White, "Burnside’s Stick in the Mud” in Diary of Wyman White, Fredericksburg National Military Park, Fredericksburg, Va. p.66

${ }^{80}$ Gerald F. Linderman, Embattled Courage: The Experience of Combat in the American Civil War. New York: Free Press, 1987. pp. 172-173.

${ }^{81}$ Harrison, Chancellorsville Battlefield Sites, p. 199-200.

${ }^{82}$ Robertson, Soliders Blue and Gray, p. 140

${ }^{83}$ Nina Silber, The Romance of Reunion: Northerners in the South 1865-1900. Chapel Hill: University of North Carolina Press, 1997.

${ }^{84}$ Silber argues, in The Romance of Reunion: Northerners in the South, 1865-1900, in an effort to reconcile differences, northerners and southerners alike celebrated the war as the true height of their respective manhood. Each man praised the bravery and virility of his worthy opponent, these notions of the ultimate forms of masculinity and manliness during war time facilitated the bridging of the sectional gap. 
${ }^{85}$ Captain J.A. Watrous, "Mosby and His Men, “ read February 2, 1887, in David Blight, Race and Reunion: The Civil War in American Memory. Cambridge: Harvard University Press, 2001. p. 198.

${ }^{86}$ Blight, Race and Reunion, p. 199.

${ }^{87}$ Private Reverend C. P. Walker. After Fredericksburg. Atlanta Journal. October 26, 1901. p. 1

${ }^{88}$ Walker, After Fredericksburg, p. 1

${ }^{89}$ David Blight's Race and Reunion is the definitive historical scholarship on Civil War Memory. Blight argues that after the war ideologies of reconciliation and emancipation were in mutual dependence of one another. However, due to hostilities and emotions still tied to the memory of the war and prewar life, race took a back seat to reunion. Blight's analysis of the reconciliationists can be used to aid in the interrogation of postwar sources on fraternization.

${ }^{90}$ Blight, Race and Reunion, p. 203.

${ }^{91}$ Blight, Race and Reunion, p. 205. 